\title{
OBSERVATIONS ON THE DRAINAGE OF AN ICE-DAMMED LAKE IN WEST GREENLAND
}

\author{
By Andrew J. Russell, John F. Aitken, and Carmen De Jong
}

(Department of Geography, University of Aberdeen, Old Aberdeen AB9 2UF, Scotland)

ABSTRACT. A small ice-dammed lake near Søndre Strømfjord, West Greenland, drained suddenly during the night of 15-16 July 1988. This drainage was observed from within the lake basin near the tunnel mouth. The drainage had four main effects: the collapse of adjacent moraine ridges; the shearing of ice around the tunnel mouth; rapid incision of the lake bed; and the transport of sediment from the lake basin into the glacier. All of the above were confined to a period of $15-30 \mathrm{~min}$ following the exposure of a circular tunnel c. $6 \mathrm{~m}$ in diameter.

\section{INTRODUCTION}

On 15 July 1988, a small ice-dammed lake near Søndre Strømfjord, West Greenland, drained suddenly. This event, together with its effects on nearby moraine ridges, the glacier margin, and the lake basin, was observed as it occurred. The lake is situated $6 \mathrm{~km}$ up-glacier from the snout of Russell Glacier (Figs 1 and 2a).

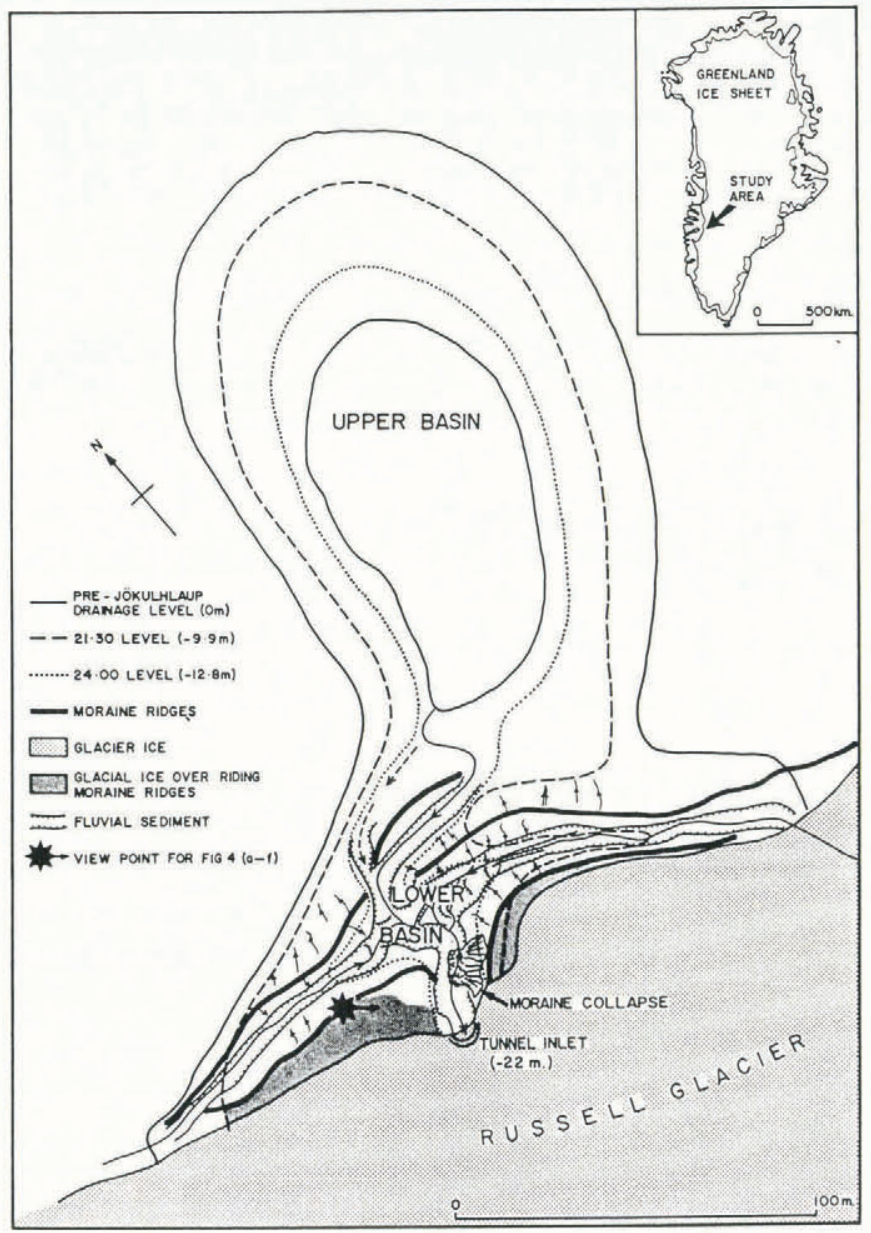

Fig. 1. Map showing the location of the field area in Greenland (inset) and the geomorphology of the lake basin.

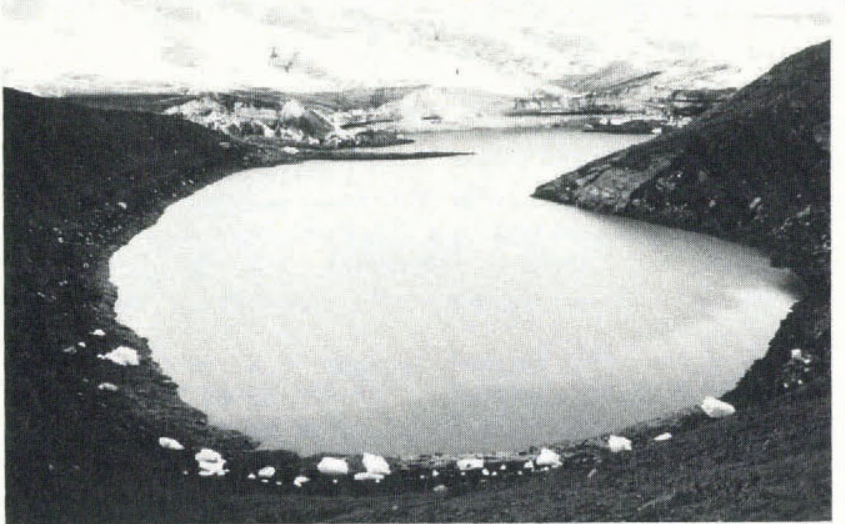

a

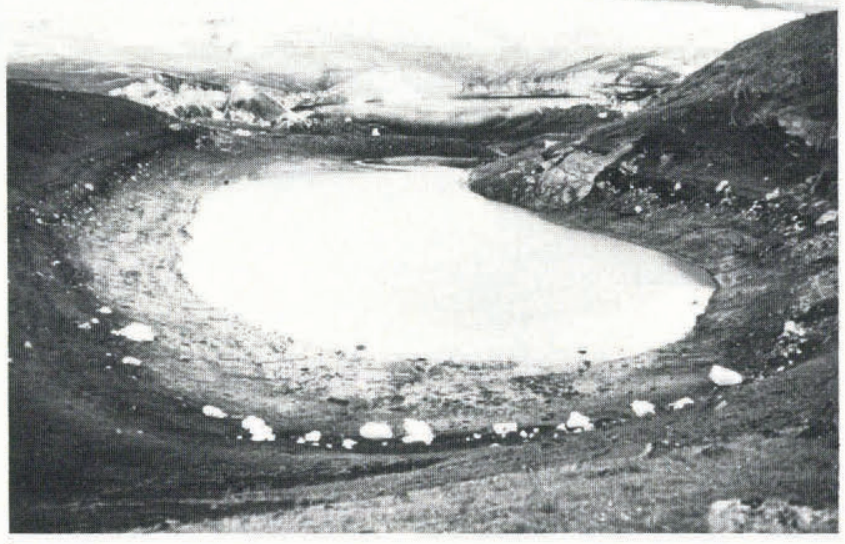

Fig. 2. View looking southward over the ice-dammed lake. (a) $21.30 \mathrm{~h}, 15 \mathrm{July} 1988$; (b) $01.00 \mathrm{~h}, 16 \mathrm{July} 1988$.

That this small lake drains periodically is suggested by air photographs of 1962 and 1968 (scale 1:17000 and $1: 40000$, respectively) which show the basin empty, and observations by one of the authors (A.J.R.) in 1987 indicate that the lake had drained in June of that year. The suitability of topographic and glaciological conditions for lake drainage along this ice margin is illustrated by the repeated drainage of a larger ice-dammed lake $1.5 \mathrm{~km}$ upglacier (Sugden and others, 1985; Gordon, 1986; Scholz and others, 1988; Russell, 1989; Russell and de Jong, in press).

\section{LAKE-BASIN MORPHOLOGY}

The lake is dammed over a distance of $250 \mathrm{~m}$ and has a maximum depth of $22 \mathrm{~m}$ (surveyed using a theodolite) adjacent to the drainage tunnel (Fig. 1). The ice margin is flanked by two moraine ridges; the first lies in close proximity to the glacier and is over-ridden by the ice in places; the second lies $100 \mathrm{~m}$ from the glacier and divides the ice-dammed lake into an upper basin (Figs 1 and $2 \mathrm{~b}$ ) and a lower basin (Figs 1 and $3 a-f$ ). Two channels dissect 

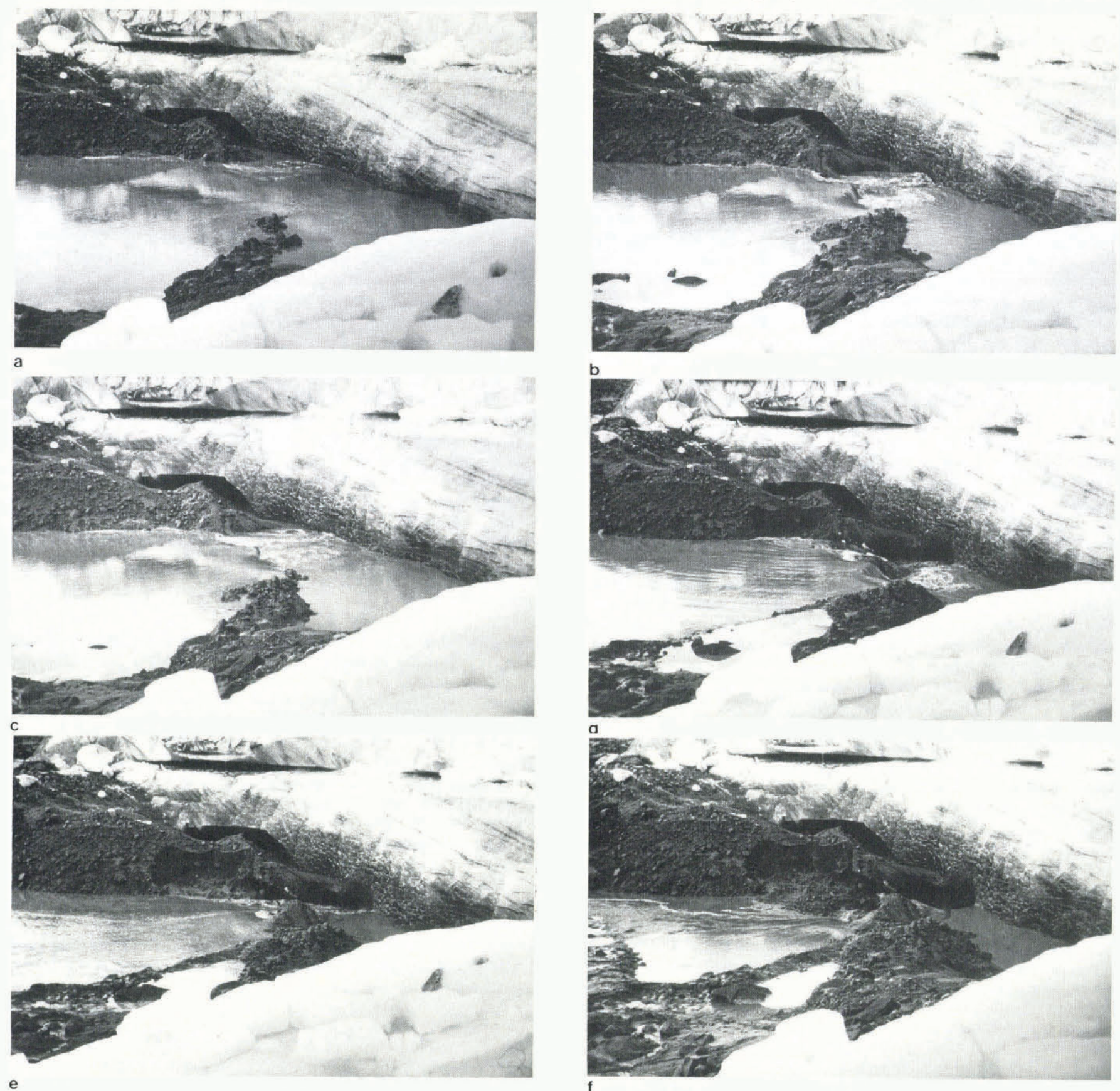

e

Fig. 3. Photographs taken from nearby moraine ridge (Fig. 2) showing jökulhlaup flows into the tunnel mouth and associated moraine collapse. (a) $00.20 \mathrm{~h}$. whirlpool above tunnel mouth; (b) 00.30 h, tunnel mouth exposed; (c) $00.35 \mathrm{~h}$, back-flow; (d) $00.40 \mathrm{~h}$. initiation of moraine collapse; (e) $00.41 \mathrm{~h}$, continuation of moraine collapse; ( $f$ ) $00.45 \mathrm{~h}$, moraine collapse exposed.

this moraine ridge and direct drainage from the upper to the lower lake basin (Figs 1 and $2 b$ ).

Lake-floor sediments comprise laminated silts, very poorly sorted moraine material containing boulders, and fluvial deposits (Figs 1 and 4). Fluvial deposits derived from the reworking of the moraines are found between the two moraine ridges where supraglacial melt streams enter the lake basin (Fig. 1). After lake drainage, these streams drain into the ice via the jökulhlaup tunnel (Fig. 4).

\section{LAKE DRAINAGE AND ITS ASSOCIATED EFFECTS} (15-16 JULY 1988)

At $21.30 \mathrm{~h}$ on $15 \mathrm{July}$, the lake was observed to be $9.9 \mathrm{~m}$ below the previous day's level (Figs 1 and 2a). Water level fell steadily by $2.9 \mathrm{~m}$ until midnight when the lake divided into the two smaller sub-basins (Figs 1 and 4). The flow velocity of lake water draining from the upper basin to the more rapidly draining lower basin increased as water

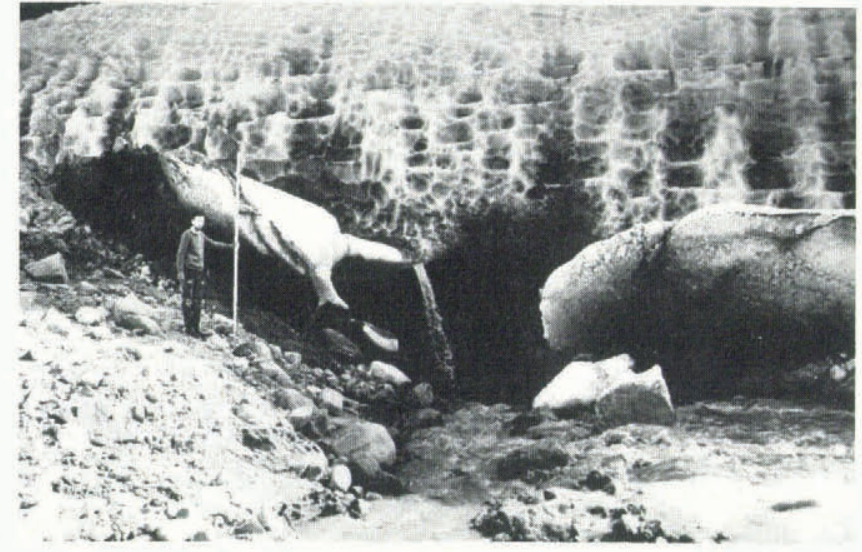

Fig. 4. Close-up of tunnel mouth (surveying staff is $3 \mathrm{~m}$ long). 
flow between the upper and lower basins was progressively confined to two main channels (Figs 1 and 4), initiating the erosion and collapse of the channel margins. Simultaneously, a whirlpool located above the tunnel entrance, adjacent to the ice front, increased in intensity until the tunnel mouth was exposed (c. $00.30 \mathrm{~h}, 16 \mathrm{July}$ ) (Fig. 3a-f). The inflow of water to the tunnel was interrupted for $10-15 \mathrm{~s}$ by a back-flow refilling the tunnel mouth. Flows of increasing velocity and turbulence were accompanied by rumbling noises which were attributed to the transport of coarse sediment derived from the moraines over the lake bed. As the rumbling noises increased in intensity, increasing amounts of coarse sediment were judged to have been transported from the lake bed into the tunnel. Flows into the tunnel were accompanied by the collapse of a $7 \mathrm{~m}$ high section of moraine near the tunnel entrance (Figs 1 and $3 a-f)$, as well as by the observed vertical shearing and displacement of glacier ice adjacent to the tunnel entrance (Fig. 1). A tremendous jarring motion was felt by the authors as the marginal ice sheared vertically.

Moraine collapse may be attributable to destabilization following the rapid lowering of lake levels in the lower basin and the undercutting of the moraine at this point by waters entering the tunnel. Sudden drop in lake levels generated high shear stress within the moraine, where high pore-water pressures may have persisted, resulting in reduction of moraine shear strength sufficient to allow undercutting to trigger a more widespread collapse $15 \mathrm{~m}$ across. The observed shearing and displacement of glacier ice near the tunnel may have resulted from the sudden release of stresses created by the rapid removal of supporting lake water.

Flows into the tunnel decreased in intensity until $01.30 \mathrm{~h}$ when the melt-water inflow from the upper to the lower basin attained equilibrium with outflow into the glacier (Fig. 2b). During the observed period of drainage, lake-floor sediments were incised by depths of up to $2 \mathrm{~m}$ over widths of $3-5 \mathrm{~m}$ by two streams entering the basin and to a lesser degree by receding lake waters producing small rills (Figs 1 and 3 ). Calculations of the volume of water drained from the lake basin were derived from a survey of lake-level fall and hypsometric data interpolated from air photographs. It is estimated that $3.3 \times 10^{5} \mathrm{~m}^{3}$ of water drained through a circular tunnel $6 \mathrm{~m}$ in diameter and cross-sectional area of $28.5 \mathrm{~m}^{2}$ within a period of at least $5 \mathrm{~h}$ (Fig. 4). Between 00.00 and $00.40 \mathrm{~h}, 4.6 \times 10^{4} \mathrm{~m}^{3}$ drained from the lake basin, corresponding to a mean discharge of about $19 \mathrm{~m}^{3} \mathrm{~s}^{-1}$.

\section{CONCLUSIONS}

These observations show that the main effects of the sudden lake drainage were the collapse of adjacent moraine ridges, the shearing of ice around the tunnel mouth, and rapid incision of the lake-basin sediments. Partly as a result of incision, sediment eroded from the lake basin was transported into the subglacial drainage system where, if retained, may provide a major source of debris to Russell Glacier. Given that many such lakes drain frequently, the above processes may supply a significant source of debris to the marginal zone of the Greenland ice sheet. These phenomena were confined to a period of $15-30 \mathrm{~min}$ of lake drainage following tunnel exposure.

\section{ACKNOWLEDGEMENTS}

We should like to thank C. and R. Peacot, J. Wood, and $K$. Swanson for assistance in the field. Financial support was gratefully received from the Aberdeen University Exploration Society, the Royal Scottish Geographical Society, and the Royal Geographical Society. A.J. Russell and J.F. Aitken are currently in receipt of U.K. Natural Environment Research Council research and training awards.

\section{REFERENCES}

Gordon, J.E. 1986. Correspondence. Glacial lake drainage near Søndre Strømfjord, West Greenland. J. Glaciol., 32(111), 304.

Russell, A.J. 1989. A comparison of two recent jökulhlaups from an ice-dammed lake, Sondre Strømfjord, West Greenland. J. Glaciol., 35(120), 157-162.

Russell, A.J. and C. de Jong. In press. Lake drainage mechanisms for the ice-dammed Oberer Russellsee, Søndre Strømfjord, West Greenland. Z. Gletscherkd. Glazialgeol.

Scholz, H., B. Schreiner, and H. Funk. 1988. Der Einfluss von Gletscherläufen auf die Schmelzwasserablagerungen des Russell-Gletschers bei Söndre Strömfjord (Westgrönland). Z. Gletscherkd. Glazialgeol., 24(1), 55-74.

Sugden, D.E., C.M. Clapperton, and P.G. Knight. 1985. A jökulhlaup near Søndre Strømfjord, West Greenland, and some effects on the ice-sheet margin. J. Glaciol., 31(109), 366-368. 